\title{
Is maternal use of selective serotonin reuptake inhibitors in the third trimester of pregnancy harmful to neonates?
}

\author{
Gideon Koren, Doreen Matsui, Adrienne Einarson, David Knoppert, Meir Steiner
}

$\mathrm{L}$ ast summer, the US Food and Drug Administration instructed manufacturers of antidepressants to issue warnings about perinatal complications associated with their products. ${ }^{1}$ Physicians were advised to taper the dosage of antidepressants in pregnant women during the last trimester so that the fetus receives no drug for at least 7-10 days before delivery. A month later, Health Canada followed suit; the Canadian advisory ${ }^{2}$ similarly suggested that "Physicians may consider slowly decreasing the dose of these medications in the third trimester." These advisories were based on "reports reveal[ing] that some newborns whose mothers took these medications during pregnancy have developed complications at birth." 2 These complications were seen as consistent with withdrawal symptoms or a direct adverse effect by the antidepressant on the baby.

We believe those recommendations are only partially evidence-based and may put the depressed mother-to-be and her baby at an unreasonable health risk. This paper presents a brief discussion of the pattern of neonatal symptoms observed after maternal use of selective serotonin or serotonin-norepinephrine reuptake inhibitors (SSRIs or SNRIs, respectively).

\section{Neonatal symptoms}

The pattern of symptoms noted in some babies of mothers who used various antidepressants near term (summarized in Box 1) is referred to as poor neonatal adaptation (PNA). When used at recommended dosages during pregnancy, neither SSRIs nor SNRIs have shown any evidence of teratogenic effects. ${ }^{3}$ This article is not intended to include discussion of the relative safety of medications taken early in pregnancy.

Along with anecdotal reports in the last decade describing complications in some babies of mothers who used various antidepressants near term, 6 studies (Table 1$)^{4-9}$ have described symptoms consistent with neonatal SSRI withdrawal or with serotonin toxicity syndrome: 3 prospective studies $^{4,5,8}$ with various methodologies, 1 case series ${ }^{6}$ and 2 database analyses. ${ }^{7,9}$ In these studies, neonatal symptoms were not universal; among babies exposed to antidepres- sants in late pregnancy, the absolute risk of PNA ranged up to $30 \%$. Notably, this pattern of symptoms was also seen in unexposed infants and those exposed early in pregnancy, at absolute rates of $6 \%-9 \%$. Near-term exposure to antidepressants increased the risk 2-fold to 10-fold, depending on the comparison group.

No reports of serious complications or death from PNA have been published to date. Although respiratory difficulties are a characteristic finding, they are generally reported as being transient, self-limiting and benign, requiring interventions for periods of only hours or days.

\section{Withdrawal versus serotoninergic syndrome}

Although the mechanism underlying PNA is not yet understood, the symptoms may result either from SSRI withdrawal or a type of serotoninergic syndrome (i.e., a toxicity phenomenon). In adults receiving SSRIs, SNRIs or tricyclic antidepressants, abrupt discontinuation has been associated with a withdrawal syndrome characterized by irritability, insomnia, nausea, vomiting, diarrhea, sweating, hot or cold flashes, tremors, dizziness and vertigo. ${ }^{10}$ The symptoms of serotoninergic syndrome in adults include confusion, restlessness, myoclonus, hyperreflexia, diaphoresis, tremor, diminished coordination and hyperthermia. ${ }^{11}$

Serotoninergic syndrome typically occurs in adults who are taking 2 or more medications that elevate brain

Box 1: Symptoms of poor neonatal adaptation

- Jitteriness

- Poor muscle tone

- Weak or absent cry

- Respiratory distress (with other causes ruled out) - Typically starts within 3 days after birth

- Occasionally requires respiratory support

- Self-limited

- Hypoglycemia

- Low Apgar score

- Seizures 
serotonin, although mild serotoninergic symptoms may be encountered among patients receiving therapeutic doses of a single SSRI. This toxicity syndrome is uncommon even in the presence of very high serum serotonin levels; it occurs, for example, in only some $14 \%$ of cases of overdose..$^{12}$ In symptomatic neonates, however, serum concentrations of SSRIs after maternal use in late pregnancy have been reported to be low or undetectable, ${ }^{13}$ which would be expected in cases of withdrawal. Among infants exposed prenatally to paroxetine (used singly), serum levels in affected babies were no higher than in those without symptoms. ${ }^{8}$

In contrast, in a recent prospective study, ${ }^{14}$ "serotonergic symptoms" were reported among neonates exposed to SSRIs in utero, who also had significantly lower umbilical-cord concentrations of 5-hydroxyindoleacetic acid. These babies exhibited serum levels of the antipressant drugs lower than (therapeutic) maternal concentrations. The so-called serotonergic symptoms that were monitored, however, were indistinguishable from those of SSRI withdrawal (e.g., restlessness and rigidity). The few symptoms that are more typical of serotoninergic syndrome (e.g., hyperthermia) went undescribed (although in the neonate fever is not a common sign). More notably, the infants did not exhibit the respiratory difficulties so prominent in the prospective cohort studies. Recently, the symptoms of an infant born with high serum levels of paroxetine, including hypertonicity, arching and mouthing, subsided with decreasing drug concentrations (D.K., personal communication). In future, careful assessment of neonatal serum SSRI concentrations will be needed to distinguish between cases of withdrawal and those of serotonin toxicity.

\section{Pharmacology}

SSRIs and SNRIs act centrally by specifically increasing levels of serotonin (and norepinephrine, in the case of SNRIs). All members of these drug classes have been shown to cross the placenta. After gestational exposure to the antidepressant(s), the newborn experiences abrupt discontinuation; hence, symptoms consistent with withdrawal are biologically plausible. In adults, the withdrawal syndrome is more prevalent with paroxetine than with fluoxetine or sertraline, possibly because the elimination half-life of paroxetine is shorter. ${ }^{15}$

All SSRIs and SNRIs are excreted in small amounts into breast milk. The question of whether neonatal withdrawal could be modified by breastfeeding while the mother takes these medications is intriguing but not yet studied. ${ }^{16}$

\section{Management}

We believe that the FDA and Health Canada advisories stating that women should consider slowly tapering off their use of antidepressants in the third trimester may be ill-conceived, even possibly dangerous. Discontinuation of antidepressants during pregnancy can lead to serious maternal morbidity (Box 2). ${ }^{3}$ Moreover, the strongest predictor of postpartum depression is depression and anxiety during pregnancy. ${ }^{17}$ In contrast, this pattern of neonatal symptoms appears to be transient. The overall health of the

\section{Table 1: Epidemiologic studies of neonatal complications after maternal use of antidepressants in late pregnancy}

\begin{tabular}{|c|c|c|}
\hline Study & Medication(s) & Neonatal outcomes \\
\hline $\begin{array}{l}\text { Chambers et al, }{ }^{4} 1996 \\
\text { Prospective cohort study }\end{array}$ & $\begin{array}{l}\text { Fluoxetine during T3, } n=73 \\
\text { Control group, } n=101 \text { (fluoxetine during T1 and T2 only) }\end{array}$ & $\begin{array}{l}\text { Relative risk (RR) for late-term exposure v. early exposure: } \\
\text { - Special-care nursery needed, RR } 2.6 \text { (CI 1.1-6.9) } \\
\text { - Poor neonatal adaptation, RR } 8.7 \text { (Cl 2.9-26.6) }\end{array}$ \\
\hline $\begin{array}{l}\text { Costei et al, }{ }^{5} 2002 \\
\text { Prospective cohort study }\end{array}$ & $\begin{array}{l}\text { Paroxetine during T3, } n=55 \\
\text { Control groups: paroxetine during T1 and T2 only, } n=27 \text {; } \\
\text { no paroxetine (but other nonteratogenic drugs), } n=27\end{array}$ & $\begin{array}{l}12 \text { study infants ( } 22 \% \text { of } 55) \text { experienced complications, } \\
\text { including } 9 \text { who had respiratory distress } \\
\text { - Odds ratio for respiratory distress, } 9.53(\mathrm{Cl} \mathrm{1.14-79.30)}\end{array}$ \\
\hline $\begin{array}{l}\text { Hendrick et al, }{ }^{6} 2003 \\
\text { Large case series }\end{array}$ & $\begin{array}{l}\text { Fluoxetine, } n=73 \text {; sertraline, } n=36 \text {; paroxetine, } n=19 ; \\
\text { citalopram, } n=7 \text {; fluvoxamine, } n=3 \text { (total } n=138 \text {; at } \\
\text { delivery, } 131 \text { women were still taking antidepressants) }\end{array}$ & $\begin{array}{l}28 \text { infants experienced complications after prenatal } \\
\text { exposure to SSRIs, an incidence considered within the } \\
\text { general population rate }\end{array}$ \\
\hline $\begin{array}{l}\text { Kallen, }{ }^{7} 2004 \\
\text { Swedish Medical Registry } \\
\text { database analysis }\end{array}$ & $\begin{array}{l}\text { Tricyclic antidepressant, } n=395 \\
\text { SSRI, } n=558 \text { (citalopram, } n=285 \text {; paroxetine, } n=106 \text {; } \\
\text { fluoxetine, } n=91 \text {; or sertraline, } n=77 \text { ) } \\
\text { Other antidepressant, } n=63 \text { (including the SNRI venla- } \\
\text { faxine, } n=24) \quad(\text { total } n=987 \text { ) }\end{array}$ & $\begin{array}{l}\text { SSRI-exposed infants v. all infants in database: } \\
\text { - Respiratory distress, odds ratio (OR) } 1.97(\mathrm{Cl} 1.38-2.83) \\
\text { - Hypoglycemia, OR } 1.35(\mathrm{Cl} 0.90-2.03) \\
\text { - Low Apgar score, OR } 2.28(\mathrm{Cl} 1.27-4.10) \\
\text { - Convulsions, risk ratio } 3.6(\mathrm{Cl} 1.0-9.3)\end{array}$ \\
\hline $\begin{array}{l}\text { Oberlander et al, } 82004 \\
\text { Prospective cohort study }\end{array}$ & $\begin{array}{l}\text { SSRI (paroxetine, fluoxetine or sertraline) with or without } \\
\text { clonazepam during T2 and T3, } n=46 \\
\text { Unexposed control group, } n=23\end{array}$ & $\begin{array}{l}\text { Poor neonatal adaptation (all with respiratory distress) } \\
\text { in } 14 \text { study infants }(30 \%) \text { and } 2 \text { control infants }(9 \%) \\
\text { - Likelihood ratio } 5.64(\mathrm{Cl} 1.1-25.3)\end{array}$ \\
\hline $\begin{array}{l}\text { Sanz et al, }{ }^{9} 2005 \\
\text { WHO database analysis* } \\
\text { of adverse drug reactions }\end{array}$ & $\begin{array}{l}\text { Among mothers of the } 93 \text { infants observed to show poor } \\
\text { neonatal adaptation: paroxetine, } n=64 \text {; fluoxetine, } n=14 \\
\text { ( } 1 \text { woman took both); sertraline, } n=9 ; \text { citalopram, } n=7\end{array}$ & $\begin{array}{l}\text { By November 2003, } 93 \text { neonatal cases of suspected } \\
\text { SSRI withdrawal were reported ( } 69 \% \text { from paroxetine); } \\
\text { regarded as enough data to confirm possible causation }\end{array}$ \\
\hline
\end{tabular}

Note: $\mathrm{Cl}=95 \%$ confidence interval, SSRI = selective serotonin reuptake inhibitor, SNRI = selective serotonin-norepinephrine reuptake inhibitor, $\mathrm{T} 1$ (T2, T3) = first (second, third) trimester.

*With the Bayesian confidence propagation neural network method. 
mother is, we believe, an important determinant of the well-being of the infant. Transient PNA may therefore represent a "lesser evil" when considering a potentially serious compromise to the mother's health.

If PNA symptoms constitute a neonatal SSRI withdrawal syndrome that is prolonged and severe, it would make sense to treat the baby with an SSRI with a long elimination halflife, such as fluoxetine. Although no prospective randomized controlled trials support the safety and efficacy of giving an SSRI or SNRI to an affected baby, 1 case report does describes an infant with signs of SNRI withdrawal and undetectable serum levels of venlafaxine..$^{18}$ When the boy was given a low dose of that drug, his symptoms did diminish. At present, fluoxetine is the only SSRI available as an oral solution, which can be suitable for newborns. In such cases, however, it would first be essential to rule out toxicity as a possible cause of the symptoms, in order to avoid administering an SSRI under circumstances when it might be harmful.

It is important that babies of mothers taking SSRIs or SNRIs be observed for longer than the typical 1-2 days post partum, so that neonatal symptoms of withdrawal or toxicity can be recognized and, if necessary, treated. Currently, affected infants are generally treated conservatively with observation (and respiratory support as required) in a special-care nursery, and tests are done to rule out microbial infection or exposure to other toxic agents (e.g., benzodiazepine, opioids or ethanol). Phenobarbital, which has a long safety record in neonates, may be used to mitigate irritability, rigidity and seizures.

In summary, the balance of evidence suggests that discontining clinically needed antidepressants in women near term is unwarranted and may put the mother at an unjustified perinatal risk. Neonatal symptoms occur in a minority of cases and are self-limited. On the basis of currently available data, regulatory agencies and manufacturers should not perpetuate anxiety among pregnant depressed women.

Any risk associated with maternal treatment with antidepressants must be weighed against the known risks associated with untreated disease (Box 2), particularly major postpartum depression. ${ }^{19}$ Such risk-benefit decisions are best made on a case-by-case basis by an informed patient in consultation with her health care provider.

\section{Box 2: Adverse effects of untreated depression during} pregnancy

Increased risk of:

- Suicidal ideation - Spontaneous abortion

- Substance abuse - Intrauterine growth retardation

- Hypertension - Low birth-weight

- Pre-eclampsia Depressive-like behaviour in the infant

- Preterm birth - Neurobehavioural changes in the infant

- Hospitalization - Postpartum depression
From the Motherisk Program, The Hospital for Sick Children and University of Toronto, Toronto, Ont. (Koren, Einarson); the Ivey Chair in Molecular Toxicology (Koren), the Department of Pediatrics, University of Western Ontario, London, Ont. (Koren, Matsui, Knoppert); and the Departments of Psychiatry and Behavioural Neurosciences and of Obstetrics and Gynecology, McMaster University, Hamilton, Ont. (Steiner)

Competing interests: None declared

Contributors: Gideon Koren planned and structured the commentary, and along with Doreen Matsui contributed data analysis and wrote the manuscript. Adrienne Einarson's contributed analysis was of maternal risk aspects; David Knoppert's, of neonatal toxicity and its definition; and Meir Steiner's, maternal psychiatric aspects, both prenatal and postpartum.

Acknowledgement: This commentary was created under the auspices of the Ivey Chair in Molecular Toxicology Consensus Initiative.

\section{References}

1. US Food and Drug Administration. FDA Medwatch Drug Alert on Effexor (venlafaxine $\mathrm{HCl}$ ) and Effexor XR (venlafaxine $\mathrm{HCl}$ ), 2004 June 3. Available: www .fda.gov/medwatch/safety/2004/safety04.htm\#effexor (accessed 2005 Apr 25).

2. Health Canada advisory of potential adverse effects of SSRIs and other antidepressants on newborns. Aug 9, 2004. Health Canada Online. Available: www.hc-sc.gc.ca/english/protection/warnings/2004/2004_44.htm (accessed 2005 Apr 25).

3. Einarson A, Selby P, Koren G. Abrupt discontinuation of psychotropic drugs during pregnancy: fear of teratogenic risk and impact of counselling. 7 Psychiatry Neurosci 2001;26:44-8.

4. Chambers CD, Johnson KA, Dick LM, Felix RJ, Jones KL. Birth outcomes in pregnant women taking fluoxetine. N Engl 7 Med 1996;335(14):1010-5.

5. Costei AM, Kozer E, Ho T, Ito S, Koren G. Perinatal outcome following third trimester exposure to paroxetine. Arch Pediatr Adolesc Med 2002;156(11): 1129-32.

6. Hendrick V, Smith LM, Suri R, Hwang S, Haynes D, Altshuler L. Birth outcomes after prenatal exposure to antidepressant medication. Am 7 Obstet Gynecol 2003;188(3):812-5.

7. Kallen B. Neonate characteristics after maternal use of antidepressants in late pregnancy. Arch Pediatr Adolesc Med 2004;158(4):312-6.

8. Oberlander TF, Misri S, Fitzgerald CE, Kostaras X, Rurak D, Riggs W. Pharmacologic factors associated with transient neonatal symptoms following prenatal psychotropic medication exposure. 7 Clin Psychiatry 2004;65:230-7.

9. Sanz EJ, De-las-Cuevas C, Kiuru A, Bate A, Edwards R. Selective serotonin reuptake inhibitors in pregnant women and the neonatal withdrawal syndrome: a database analysis. Lancet 2005;365(9458):482-7.

10. Coupland NJ, Bell CJ, Potokar JP. Serotonin reuptake inhibitor withdrawal. 7 Clin Psychopharmacol 1996;16:356-62.

11. Sternbach H. The serotonin syndrome [review]. Am f Psychiatry 1991;148:705-13.

12. Isbister GK, Bowe SJ, Dawson A, Whyte IM. Relative toxicity of selective serotonin reuptake inhibitors (SSRIs) in overdose. 7 Toxicol Clin Toxicol 2005. 42:277-85.

13. Misri S, Kim J, Riggs KW, Kostaras X. Paroxetine levels in postpartum depressed women, breast milk, and infant serum. 7 Clin Psychiatry 2000;61:828-32.

14. Laine K, Heikkinen T, Ekblad U, Kero P. Effects of exposure to selective serotonin reuptake inhibitors during pregnancy on serotonergic symptoms in newborns and cord blood monoamine and prolactin concentrations. Arch Gen Psychiatr 2003;60:720-6.

15. Rosenbaum JF, Fava M, Hoog SL, Ascroft RC, Krebs WB. Selective serotonin reuptake inhibitor discontinuation syndrome: a randomized clinical trial. Biol Psychiatry 1998;44:77-87.

16. Newport DJ, Hostetter A, Arnold A, Stowe ZN. The treatment of postpartum depression: minimizing infant exposure [review]. 7 Clin Psychiatry 2002; 63(Suppl 7):31-44.

17. Beck CT. Revision of the Postpartum Depression Predictors Inventory [review]. 7 Obstet Gynecol Neonatal Nurs 2002;31(4):394-402.

18. De Moor RA, Mourad L, ter Haar J, Egberts AC. [Withdrawal symptoms in a neonate following exposure to venlafaxine during pregnancy]. Ned Tijdschr Geneeskd 2003;147(28):1370-2.

19. Bonari L, Bennett H, Einarson A, Koren G. Risks of untreated depression in pregnancy. Can Fam Physician 2004;50:37-9.

Correspondence to: Dr. Gideon Koren, Division of Clinical Pharmacology, The Hospital for Sick Children, 555 University Ave., Toronto ON M5G 1X8; fax 416 813-7562;

gkoren@sickkids.ca 